\title{
Daytime Restricted Feeding Modifies the Temporal Expression of CYP1A1 and Attenuated Damage Induced by Benzo[a]pyrene in Rat Liver When Administered before CYP1A1 Acrophase
}

\author{
Oscar Samuel Ávila-Rosales ${ }^{1}$, Mauricio Díaz-Muñoz ${ }^{2}{ }^{(0)}$, Rafael Camacho-Carranza ${ }^{1}{ }^{(}$, Elvia Coballase-Urrutia ${ }^{3}{ }^{\circledR}$, \\ José Pedraza-Chaverri ${ }^{4}{ }^{\mathbb{D}}$, Jorge Omar García-Rebollar ${ }^{1}$ and Jesús Javier Espinosa-Aguirre ${ }^{1, *}$ \\ 1 Instituto de Investigaciones Biomédicas, Universidad Nacional Autónoma de México, \\ Ciudad de México 04510, Mexico; x-li@live.com.mx (O.S.Á.-R.); rcamacho@iibiomedicas.unam.mx (R.C.-C.); \\ Jorgerebollar@biomedicas.unam.mx (J.O.G.-R.) \\ 2 Instituto de Neurobiología, Universidad Nacional Autónoma de México, Querétaro 76230, Mexico; \\ mdiaz@comunidad.unam.mx \\ 3 Laboratorio de Neurociencias, Instituto Nacional de Pediatría, Ciudad de México 04530, Mexico; \\ elcoballase@yahoo.com.mx \\ 4 Departamento de Biología, Facultad de Química, Universidad Nacional Autónoma de México, \\ Ciudad de México 04510, Mexico; pedraza@unam.mx \\ * Correspondence: jjea@iibiomedicas.unam.mx
}

check for updates

Citation: Ávila-Rosales, O.S.; Díaz-Muñoz, M.; Camacho-Carranza, R.; Coballase-Urrutia, E.; Pedraza-Chaverri, J.; García-Rebollar, J.O.; Espinosa-Aguirre, J.J. Daytime Restricted Feeding Modifies the Temporal Expression of CYP1A1 and Attenuated Damage Induced by Benzo[a]pyrene in Rat Liver When Administered before CYP1A1 Acrophase. Toxics 2021, 9, 130. https://doi.org/10.3390/toxics9060130

Academic Editor: Yoshinori Ikenaka

Received: 3 May 2021

Accepted: 2 June 2021

Published: 4 June 2021

Publisher's Note: MDPI stays neutral with regard to jurisdictional claims in published maps and institutional affiliations.

Copyright: (c) 2021 by the authors. Licensee MDPI, Basel, Switzerland. This article is an open access article distributed under the terms and conditions of the Creative Commons Attribution (CC BY) license (https:// creativecommons.org/licenses/by/ $4.0 /)$.

\begin{abstract}
The aryl hydrocarbon receptor (AhR) is a ligand-activated transcription factor that heterodimerizes with the AhR nuclear translocator (ARNT) to modulate CYP1A1 expression, a gene involved in the biotransformation of benzo[a]pyrene $(\mathrm{BaP})$. The AhR pathway shows daily variations under the control of the circadian timing system. Daytime restricted feeding (DRF) entrains the expression of genes involved in the processing of nutrients and xenobiotics to food availability. Therefore, we evaluate if temporal $A h R, A R N T$, and CYP1A1 hepatic expression in rats are due to light/dark cycles or fasting/feeding cycles promoted by DRF. Our results show that $A h R$ oscillates throughout the $24 \mathrm{~h}$ period in DRF and ad libitum feeding rats (ALF), showing maximum expression at the same time points. DRF modified the peak of ARNT expression at ZT5; meanwhile, ALF animals showed a peak of maximum expression at ZT17. An increased expression of CYP1A1 was linked to the meal time in both groups of animals. Although a high CYP1A1 expression has been previously associated with BaP genotoxicity, our results show that, compared with the ALF group, DRF attenuated the BaP-CYP1A1 induction potency, the liver DNA-BaP adducts, the liver concentration of unmetabolized $\mathrm{BaP}$, and the blood aspartate aminotransferase and alanine aminotransferase activities when $\mathrm{BaP}$ is administered prior to the acrophase of CYP1A1 expression. These results demonstrate that DRF modifies the ARNT and CYP1A1 expression and protects from BaP toxicity.
\end{abstract}

Keywords: cytochrome P450; benzo[a]pyrene; liver; DNA damage; daytime restricted feeding

\section{Introduction}

Polycyclic aromatic hydrocarbons (PAHs) are hydrophobic compounds formed and released during incomplete combustion, volcanic eruptions, and diagenesis [1]. The use of petroleum products has increased the concentration of PAHs in the environment [2], and the main sources of exposure to PAHs in humans are cigarette smoke and grilled food [3]. Benzo[a]pyrene $(\mathrm{BaP})$ is considered the prototypical PAH due to its widely studied cytotoxic, mutagenic, and carcinogenic properties [4].

Aryl hydrocarbon receptor (AhR) is a receptor/transcription factor that recognizes $\mathrm{BaP}$, heterodimerizes with $\mathrm{AhR}$ nuclear translocator (ARNT), and regulates multiple genes, including members of the cytochrome P450 (CYP) family, such as CYP1A1 [5]. CYP1A1 metabolizes $\mathrm{BaP}$ into hydrophilic compounds such as 7,8-diol-BaP [6]. However, 7,8-diol$\mathrm{BaP}$ can be metabolized again by CYP1A1 to yield the highly electrophilic metabolite 7,8- 
diol-9,10-epoxy-BaP (BPDE) [7] that forms DNA adducts [8], thereby promoting mutagenic and carcinogenic processes [9].

Previous reports indicate that $A h R$ expression in rodent liver and lungs show temporal variations $[10,11]$. These temporal variations are under the control of humoral and neural signals from the suprachiasmatic nucleus (SCN) [12]. Daytime restricted feeding (DRF) is an experimental protocol that limits food access at $2-4 \mathrm{~h}$ periods/day during the light period [13]. This fasting/feeding cycle modifies the temporal organization of the liver, kidney, heart, and pancreas activities independently of the SCN [14]. This is achieved through changes in the temporal expression of enzymes involved in the metabolism of lipids, glucose, and urea during the food access period [15-18].

Additionally, animals exposed to DRF show a decreased toxicity and bioavailability of gentamicin [19], attenuation of acetaminophen toxicity [20], prevention of neoplastic transformation induced by diethylnitrosamine [21], and decreased rates of metastasis when fed with a high-lipid diet [22]. We aimed to determine the effect of DRF on the temporal expression of $A h R, A R N T$, and CYP1A1, and its influence on BaP-induced hepatotoxicity.

\section{Materials and Methods}

\subsection{Chemicals}

Benzo[a]pyrene, corn oil, moloney murine leukemia virus reverse transcriptase (MMVL RT), ethylenediaminetetraacetic acid calcium disodium salt (EDTA), DL-dithiothreitol (DTT), glycerol, magnesium chloride $\left(\mathrm{MgCl}_{2}\right)$, ethoxyresorufin-O-deethylase (EROD), resorufin sodium salt (RES), dihydronicotinamide adenine dinucleotide phosphate tetrasodium salt (NADPH), ethylene glycol-bis(2-aminoethylether)- $N, N, N^{\prime}, N^{\prime}$-tetraacetic acid (EGTA), dimethyl sulfoxide (DMSO), sucrose, sodium dodecyl sulfate (SDS), Proteinase K, and RNase were all purchased from Sigma-Aldrich (St. Louis MO, USA). Potassium chloride $(\mathrm{KCl})$, sodium chloride $(\mathrm{NaCl})$, monobasic potassium phosphate $\left(\mathrm{KH}_{2} \mathrm{PO}_{4}\right)$, dibasic potassium phosphate $\left(\mathrm{K}_{2} \mathrm{HPO}_{4}\right)$, phenol, chloroform, isoamyl alcohol, and ethanol were all purchased from JT Baker (Mexico City, Mexico). Trizol was purchased from Invitrogen (Carlsbad, CA, USA). SYBR Green TaqMan Universal PCR Master Mix was acquired from Applied Biosystems (Foster City, CA, USA). Bradford protein assay reagent, Tris Base, polyacrylamide, bis-acrylamide, nitrocellulose membranes, and Tween 20 were all purchased from Bio-Rad Laboratories Inc. (Hercules, CA, USA). Amersham ECL Prime Western Blotting Detection Reagent was acquired from GE Healthcare Life Sciences (Chicago, IL, USA). Mouse monoclonal anti-CYP1A1 (393979) and horseradish peroxidase (HRP)-conjugated secondary antibodies (sc-2354) were acquired from Santa Cruz Biotechnology, Inc. (Dallas, TX, USA). Mouse monoclonal anti-GAPDH (GTX627408) was from GeneTex (Irvine, CA, USA). DNase-free water was acquired from GibcoBRL (Waltham, MA, USA). The BPDER DNA adduct ELISA Kit was acquired from Cell BIOLABS, Inc. (San Diego, CA, USA).

\subsection{Animals}

Adult male Wistar rats, 6 weeks old at the beginning of the experiments, were maintained under a 12:12 h light/dark cycle (ZT0 was lights on and ZT12 lights out) and a constant temperature $\left(22 \pm 1{ }^{\circ} \mathrm{C}\right)$, with free access to tap water and food (LabDiet $5001^{\mathrm{TM}}$ ) for at least one week before the initiation of the experiments. Rats were housed in transparent acrylic cages $(40 \times 50 \times 20 \mathrm{~cm})$ with sani-chips bedding $\left(\right.$ Envigo $\left.^{\mathrm{TM}}\right)$. All experimental procedures were approved and conducted according to the institutional guide for the care and use of animals under biomedical experimentation (Neurobiology Institute, National Autonomous University of Mexico), under the protocol \#33 ratified by the Bioethical Committee of Neurobiology Institute (September 2006) and conformed to previously recommended international ethical standards [23]. 


\subsection{Animal Treatment}

\subsubsection{Daytime Restricted Feeding}

To examine if the $A h R, A R N T$, and CYP1A1 mRNA acrophase (temporal expression peak) is due to either light/dark cycles or fasting/feeding cycles, we chose the DRF protocol. The animals were placed randomly in one of the following groups: (a) ad libitum feeding (ALF) with free access to water and food, or (b) DRF with access to food from ZT4 to ZT6 for 21 days and free access to water. To determine that the observed effects were neither due to an acute $21 \mathrm{~h}$ food-deprivation interval nor to the refeeding after fasting, two additional control groups were included: (c) fasted (Fa), with free access to water and food for 21 days, that were then fasted for $21 \mathrm{~h}$, and (d) rats with free access to water and food for 21 days, that were then fasted for $21 \mathrm{~h}$ and refed (Re) for $2 \mathrm{~h}$ (from ZT4 to ZT6). Four rats per group (ALF and DRF) were sacrificed by decapitation at ZT0, ZT3, ZT6, ZT9, ZT12, ZT15, ZT18, and ZT21. The Fa and Re rats were sacrificed (four rats per group) at ZT3 (after $21 \mathrm{~h}$ fasting) and ZT6 (after $21 \mathrm{~h}$ fasting and immediately after $2 \mathrm{~h}$ refeeding), respectively.

\subsubsection{Exposure to $\mathrm{BaP}$}

For genotoxic analysis, the animals were distributed randomly in the ALF or DRF groups. Each group was further divided into three subgroups: (a) the control subgroup, which was sacrificed by decapitation (six rats per group) on the 21st day (DRF group at ZT1 and ALF group at ZT13), or (b) corn oil subgroup, which was intraperitoneally (i.p.) injected on the 21st day with $0.3 \mathrm{~mL}$ corn oil at ZT1 (DRF group) and ZT12 (ALF group) and sacrificed by decapitation (six rats per group) at $24 \mathrm{~h}$ after administration. Due to the large number of handled animals, this subgroup was included in a preliminary experiment including a control subgroup, (c) the BaP subgroup, which was i.p. injected on the 21st day with $10 \mathrm{mg} / \mathrm{kg}$ body weight of $\mathrm{BaP}$ in $0.3 \mathrm{~mL}$ corn oil at ZT1 (DRF group) and ZT13 (ALF group) and sacrificed by decapitation (six rats per group) at 24, 48, and $72 \mathrm{~h}$ after BaP administration. We chose i.p. administration to ensure the absorption of $\mathrm{BaP}$ from the peritoneal cavity by the portal system and its subjection to the hepatic first-pass elimination [24].

\subsection{AhR, ARNT, and CYP1A1 Expression}

Total liver RNA was isolated using the TRIzol method [25], and $1 \mu \mathrm{g}$ of total RNA was reverse-transcribed using M-MVL RT following the manufacturer's instructions. qPCR for $A h R, A R N T, C Y P 1 A 1$, and RPS18 (Table 1) was performed with SYBR Green TaqMan Universal PCR Master Mix. Fluorescence was monitored on a CFX96 real-time system (Bio-Rad Laboratories Inc., Hercules, CA, USA), efficiency curves were made for each probe, and the relative expression was calculated using the $2^{-\Delta \Delta \mathrm{Ct}}$ mathematical analysis method [26].

Table 1. Primer sequences for amplification of rat AhR, ARNT, CYP1A1, and RPS18 by real-time PCR.

\begin{tabular}{cccc}
\hline Gene & NCBI RefSeq & Forward & Reverse \\
\hline AhR & NM_013149.3 & $5^{\prime}$-gggccaagagcttctttgatg-3' & $5^{\prime}$-gcaagtcctgccagtctctga-3' \\
\hline ARNT & NM_012780 & $5^{\prime}$-agagacttgccagggaaaatcata-3' & $5^{\prime}$-tttcgagccagggcactacagg-3' \\
\hline CYP1A1 & NM_012540.2 & $5^{\prime}$-gggccaagagcttctttgatg-3' & $5^{\prime}$-gtcccggatgrggcccttctcaaa-3' \\
\hline RPS18 & NM_213557.1 & $5^{\prime}$-ttcagcacatcctgcgagta-3 & $5^{\prime}$-ttggtgaggtcaatgtctgc-3' \\
\hline
\end{tabular}

\subsection{Subcellular Fractionation}

Three grams of liver were homogenized in $6 \mathrm{~mL}$ of $0.15 \mathrm{mM} \mathrm{KCl}$. The homogenate was centrifuged at $9000 \times g$ for 20 min in a Beckman $\mathrm{J} 2 \mathrm{MC}^{\mathrm{TM}}$ centrifuge, and the supernatant was centrifuged at $100,000 \times g$ for $60 \mathrm{~min}$ in a Beckman Coulter ${ }^{\mathrm{TM}}$ centrifuge. The pellet was resuspended in $6 \mathrm{~mL}$ of buffer $0.1 \mathrm{M} \mathrm{K}_{2} \mathrm{HPO}_{4}, \mathrm{pH} 7.4$, and was centrifuged under the 
same conditions. The pellet was resuspended in $2 \mathrm{~mL}$ of microsome buffer $1 \mathrm{mM}$ EDTA, $1 \mathrm{mM}$ DTT, and $20 \%$ glycerol.

\subsection{Protein Quantification}

Protein quantification was performed according to Bradford [27], with some modifications in order to allow the acquisition of the results from a microplate. We used $10 \mu \mathrm{L}$ of a 1:80 dilution of each sample with $200 \mu \mathrm{L}$ of a 1:4 dilution of the Bradford protein assay reagent. Data were normalized with a bovine serum albumin standard curve.

\subsection{CYP1A1 Immunodetection}

Per lane of hepatic microsomal proteins, $20 \mu \mathrm{g}$ were separated by $10 \%$ SDS-polyacrylamide gel electrophoresis under reducing conditions, transferred to $0.45 \mu \mathrm{m}$ nitrocellulose membranes, and blocked for $1 \mathrm{~h}$ in TBST buffer with $20 \mathrm{mM}$ Tris base, $0.5 \mathrm{M} \mathrm{NaCl}$, and $0.5 \%$ Tween $20 \mathrm{pH}$ 7.5. Then, the membrane was incubated overnight at $4{ }^{\circ} \mathrm{C}$ with a monoclonal CYP1A1 antibody or a monoclonal GAPDH antibody, which was diluted 1:2000 (in TBST buffer). After washing, the membranes were incubated with a mouse anti-goat secondary antibody coupled to horseradish peroxidase diluted 1:10,000. The chemiluminescence reaction was performed with an Amersham ECL Prime Western Blotting Detection Reagent. Densitometric analysis was performed using Kodak Image Software (v 3.0).

\subsection{CYP1A1 Activity Assay}

The assay was performed according to the original protocol [28], with some modifications in order to allow the acquisition of the results from a microplate. Forty $\mu \mathrm{g}$ of microsomal protein were incubated at $37^{\circ} \mathrm{C}$ for $3 \mathrm{~min}$ with $150 \mu \mathrm{L}$ activity buffer $(150 \mathrm{mM}$ Tris base and $25 \mathrm{mM} \mathrm{MgCl} 2$ ) and $5 \mu \mathrm{L}$ of $50 \mathrm{M}$ EROD solution. The reaction was started by adding $40 \mu \mathrm{L}$ of $5 \mathrm{mM}$ NADPH. The fluorescence assay $(520 \mathrm{~nm}$ excitation, $585 \mathrm{~nm}$ emission) was performed with a Synergy $\mathrm{H}^{\mathrm{TM}}$ microplate reader (Biotek Instruments Inc., Winooski, VT, USA). Data were normalized according to the resorufin curve.

\subsection{BPDE-DNA Assay}

For rat liver, $200 \mu \mathrm{g}$ were homogenized individually in lysis buffer $(0.35 \mathrm{M}$ sucrose, $30 \mathrm{mM}$ Tris base, and $2 \mathrm{mM}$ EGTA, pH 7.4) and centrifuged at $12,000 \times g$ for $10 \mathrm{~min}$ at $4{ }^{\circ} \mathrm{C}$ in a MIKRO 200R, Hettich ${ }^{\circledR}$. The pellet was resuspended in extraction buffer $(10 \mathrm{mM}$ Tris base, $10 \mathrm{mM}$ EDTA, $100 \mathrm{mM} \mathrm{NaCl}$, and $2 \%$ SDS, pH 8.0, with $10 \mu \mathrm{L}$ proteinase $\mathrm{K}$ ) and incubated at $57^{\circ} \mathrm{C}$ for $2 \mathrm{~h}$. Finally, $800 \mu \mathrm{L}$ of phenol/chloroform/isoamyl alcohol (25:24:1) was mixed with the sample, which was centrifuged at $11,000 \times g$ for $10 \mathrm{~min}$. The supernatant was collected, and $3 \mu \mathrm{L}$ of RNase was added. The mixture was incubated for $60 \mathrm{~min}$ at room temperature. Then, $500 \mu \mathrm{L}$ of phenol/chloroform/isoamyl alcohol (25:24:1) was added and the mixture was centrifuged at $11,000 \times g$ at $4{ }^{\circ} \mathrm{C}$ for $10 \mathrm{~min}$. The aqueous phase was collected, and $400 \mu \mathrm{L}$ of ethanol was added. The sample was centrifuged at $14,000 \times g$ at $4{ }^{\circ} \mathrm{C}$ for $20 \mathrm{~min}$. The supernatant was discarded, and $1 \mathrm{~mL}$ of $70 \%$ ethanol was added and centrifuged at $14,000 \times g$ for $10 \mathrm{~min}$, and the pellet was resuspended in DNase-free water. The DNA was quantified in a Nanodrop 2000 (ThermoScientific ${ }^{\mathrm{TM}}$ ).

We used the BPDE DNA adduct ELISA Kit; briefly, the DNA samples were tested with an anti-BPDE-I antibody, followed by an HRP conjugated secondary antibody, according to the manufacturer's instructions. The absorbance assay $(450 \mathrm{~nm})$ was performed with a Synergy $\mathrm{H} 4^{\mathrm{TM}}$ microplate reader. The BPDE-DNA adduct content in samples was determined by comparing with a standard curve that was prepared from predetermined BPDE-DNA standards $[29,30]$.

\subsection{Serum Aspartate Aminotransferase (AST) and Alanine Aminotransferase (ALT) Activities}

Blood was collected immediately after decapitation and serum was separated by centrifugation at $6000 \times g$ for 15 min $\left(\right.$ MIKRO 200R, Hettich $\left.{ }^{\circledR}\right)$, and the supernatant was kept at $-80^{\circ} \mathrm{C}$ until analysis. AST and ALT activities were determined according to the 
International Federation of Clinical Chemistry [31] procedure with the Beckman Coulter UniCel ${ }^{\circledR}$ DxC600 Chemistry Analyzer.

\subsection{BaP Quantification Assay}

$\mathrm{BaP}$ was measured in $40 \mu \mathrm{L}$ of rat liver homogenate, $160 \mu \mathrm{L}$ of DMSO was added, and the fluorescence intensity was measured ( $470 \mathrm{~nm}$ emission, $380 \mathrm{~nm}$ excitation) [32] with a Synergy $\mathrm{H} 4^{\mathrm{TM}}$ microplate reader. Data were normalized according to the results for $\mathrm{BaP}$ dissolved in DMSO obtained under the same conditions.

\subsection{Statistical Analysis}

The statistical analysis was performed using GraphPad Prism software (v 6.0; San Diego, CA, USA). The normality distribution and equal variances were determined by the Kolmogorov-Smirnov and Levene tests. The results for different time points were compared using a one-way analysis of variance (ANOVA), and the groups were compared using two-way ANOVA; in both cases, ANOVA was followed by a post hoc Bonferroni test. All pairwise multiple comparisons were performed by Student's $t$-test. Differences among groups were considered statistically significant when $p \leq 0.05$. For rhythmic interpretation, we considered: acrophase, MESOR, and amplitude calculated with COSANA software (v 3.1 developed by AA Benedito-Silva, GMDRB, ICB/USP, Sao Paulo, Brazil), according to Refenetti et al. [33].

\section{Results}

\subsection{Liver AhR, ARNT, and CYP1A1 Expression in ALF and DRF Groups}

In rats, under ALF, AhR, ARNT, and CYP1A1 mRNA oscillate throughout the $24 \mathrm{~h}$ period, showing maximum expression at the interval ZT14 to ZT17 during the dark phase (Figure 1, Table 2). The DRF feeding protocol does not modify the $A h R$ peak but suppresses the ARNT peak observed in the ALF group at ZT17 (Figure 1A,B, Table 2). It seems that the $A R N T$ expression in the animals under DRF is constant throughout the $24 \mathrm{~h}$ period, with an expression peak at ZT5 (Figure 1B, Table 2). Surprisingly, in the DRF group, we observed a maximum peak in CYP1A1 expression at ZT5 that is 15.6-fold higher than that in the ALF group at the same time, but showed the same level of expression at ZT17 (Figure 1C, Table 2). Additionally, no differences were observed in AhR, ARNT, and CYP1A1 mRNA levels between the ALF, Fa, or Re groups.

Table 2. Chronobiological parameters obtained by Cosinor analysis for the effects of DRF on $A h R$, $A R N T$, and CYP1A1 expression.

\begin{tabular}{ccccccc}
\hline & \multicolumn{2}{c}{ Mesor } & \multicolumn{2}{c}{ Amplitude } & \multicolumn{2}{c}{ Acrophase } \\
\cline { 2 - 7 } & ALF & DRF & ALF & DRF & ALF & DRF \\
\hline \multirow{2}{*}{ AhR } & 0.128 & 0.164 & 0.091 & 0.084 & ZT14 & ZT14 \\
& \pm 0.014 & \pm 0.017 & \pm 0.026 & \pm 0.027 & \pm 1.936 & \pm 2.44 \\
\hline \multirow{2}{*}{ ARNT } & 0.115 & 0.094 & 0.128 & 0.043 & ZT17 & ZT5 \\
& \pm 0.02 & \pm 0.047 & \pm 0.03 & $\pm 0.007^{\alpha}$ & \pm 0.75 & $\pm 1.43^{\alpha}$ \\
\hline \multirow{2}{*}{ CYP1A1 } & 0.055 & 0.205 & 0.056 & 0.207 & ZT17 & ZT5 \\
& \pm 0.009 & $\pm 0.031^{\alpha}$ & \pm 0.018 & $\pm 0.041^{\alpha}$ & \pm 1.436 & $\pm 3.86^{\alpha}$ \\
\hline
\end{tabular}

Each data point corresponds to the mean $+\mathrm{SEM}, n=4 .{ }^{\alpha} p \leq 0.05$ compared to the ALF group. 
A

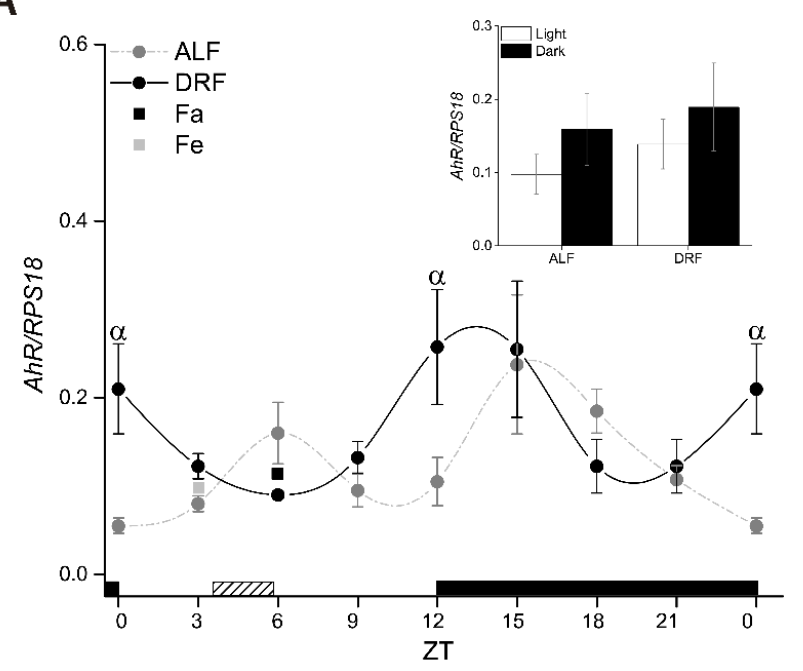

B

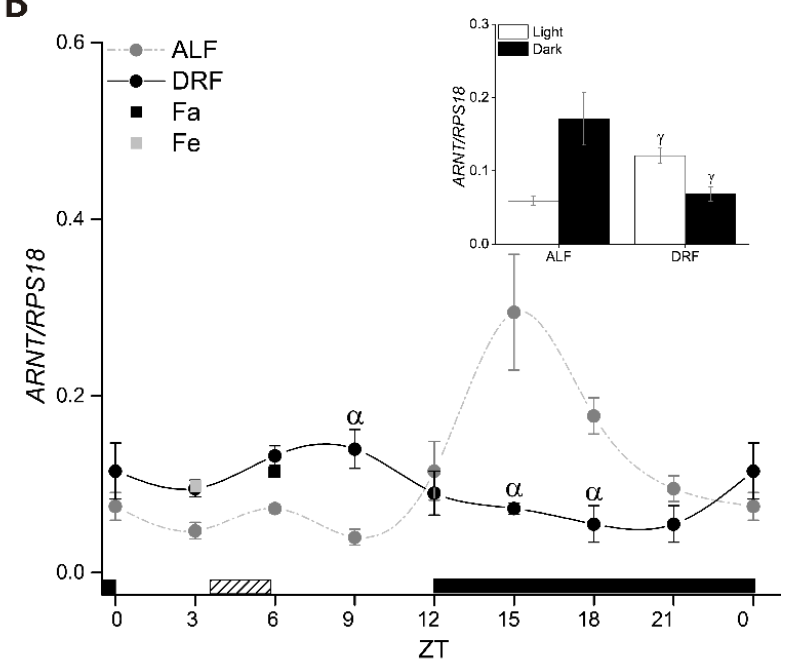

C

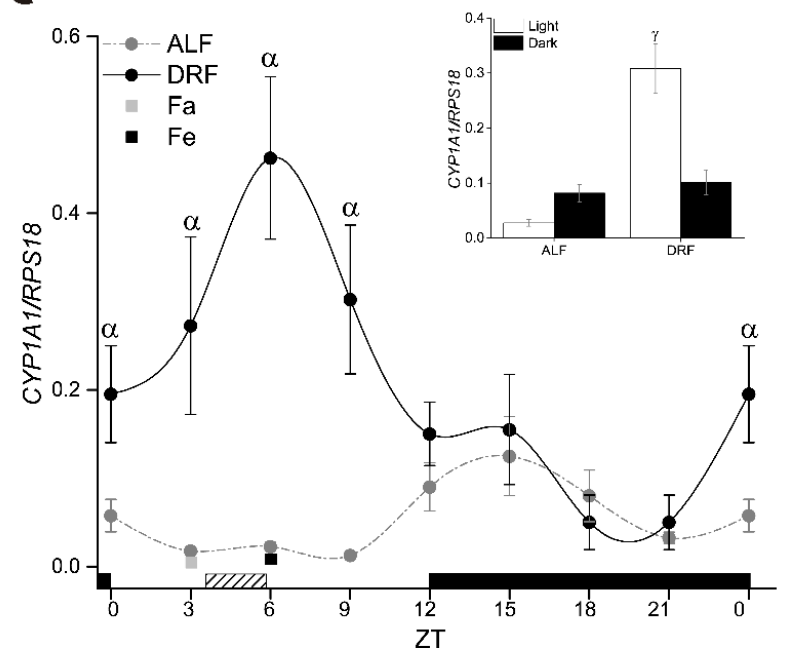

Figure 1. Temporal expression of $A h R$ mRNA (A), ARNT (B), and CYP1A1 mRNA (C) in the livers of rats in the ALF (gray circles), DRF (dark circles), Fa (gray squares), and Fe (dark squares) groups. The dark box corresponds to the dark period (ZT12 to ZT0), and the dashed box corresponds to the food access period for the DRF group. Each point represents the mean \pm SEM, $n=4 . \alpha p \leq 0.05$ compared to the ALF group at the same time points. $\gamma p \leq 0.05$ compared to the ALF group. White bars correspond to the mean \pm SEM of all data for the light period, and black bars correspond to the mean \pm SEM of all data for the dark period. Points of the same group with significant difference: AhR in ALF group: ZT0 vs. ZT15 and ZT0 vs. ZT18; AhR in DRF group: ZT6 vs. ZT12 and ZT6 vs. ZT15. ARNT in ALF group ZT15 vs. ZT21, ZT15 vs. ZT0, ZT15 vs. ZT3, ZT15 vs. ZT6, and ZT15 vs. ZT9; ARNT in DRF group: ZT9 vs. ZT18, ZT9 vs. ZT21, and ZT9 vs. ZT15. CYP1A1 in ALF group: ZT15 vs. ZT3, ZT15 vs. ZT6, and ZT15 vs. ZT9; CYP1A1 in DRF group: ZT6 vs. ZT12, ZT6 vs. ZT15, ZT6 vs. ZT18, and ZT6 vs. ZT21.

\subsection{BaP Administration Time}

Previous studies associated a high CYP1A1 expression with an increase in BPDE adducts [8]. In this work, rats under DRF show a high CYP1A1 expression at mealtime. These results suggests that the period before mealtime in rats under DRF may promote an additive increase in CYP1A1 induction after BaP exposure as well as an increase in BaP toxicity. To test this hypothesis, we compared the acrophase during both DRF and ALF. Our Cosinor analysis showed that the acrophases were at ZT5 and ZT17 in rats under DRF and ALF, respectively (Table 2). For this reason, we carried out BaP administration $4 \mathrm{~h}$ before the acrophase (at ZT1 in the DRF group and at ZT13 in the ALF group), with the purpose of guaranteeing the BaP absorption by the liver [24]. 


\subsection{DRF Attenuates the Induction of Hepatic CYP1A1 Expression by BaP}

In rats under ALF, the maximum CYP1A1 mRNA expression was observed at $24 \mathrm{~h}$ after $\mathrm{BaP}$ administration (1237-fold compared with the ALF control group, $p \leq 0.05$, Figure 2A) and decreased over the subsequent hours. Consistent with the abundance of CYP1A1 mRNA, its protein level and activity were increased 227- and 14-fold respectively, at $24 \mathrm{~h}$ ( $p \leq 0.05$, compared with the ALF control group), and both were maintained until $72 \mathrm{~h}$ after $\mathrm{BaP}$ exposure (Figure 2B-D).

A

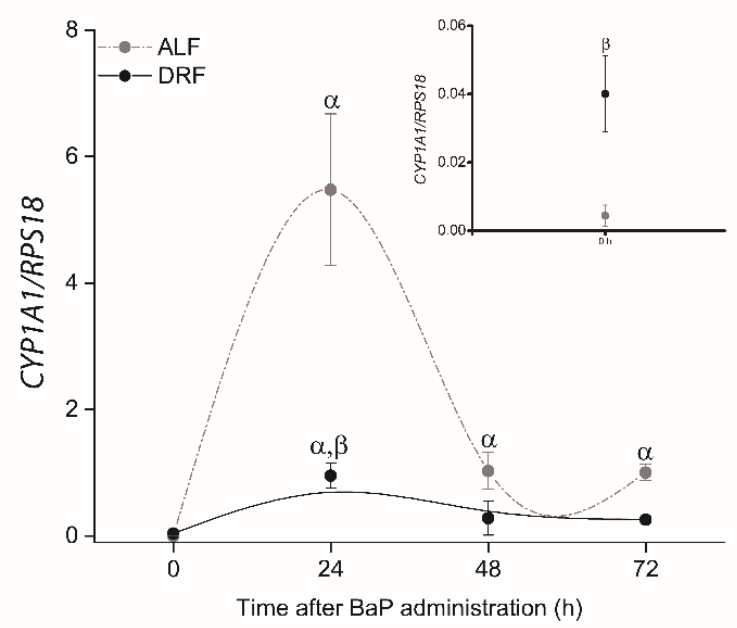

C

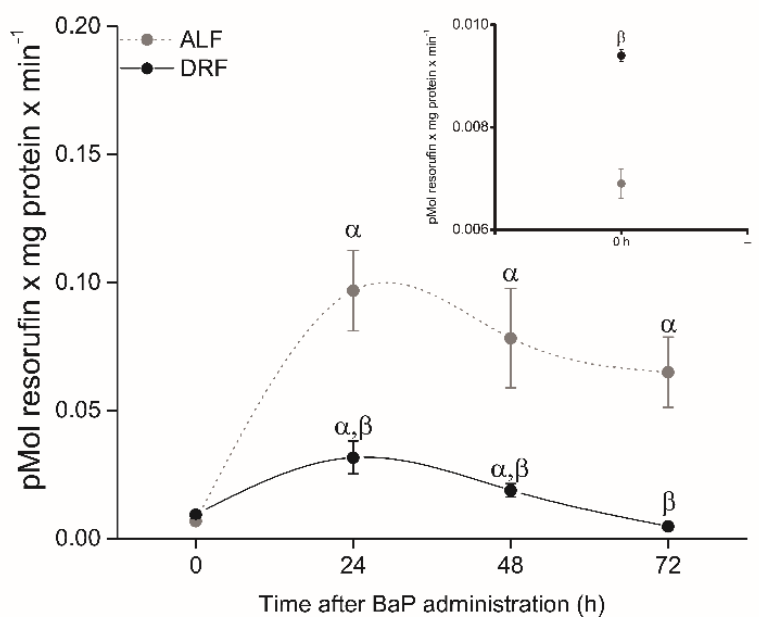

B

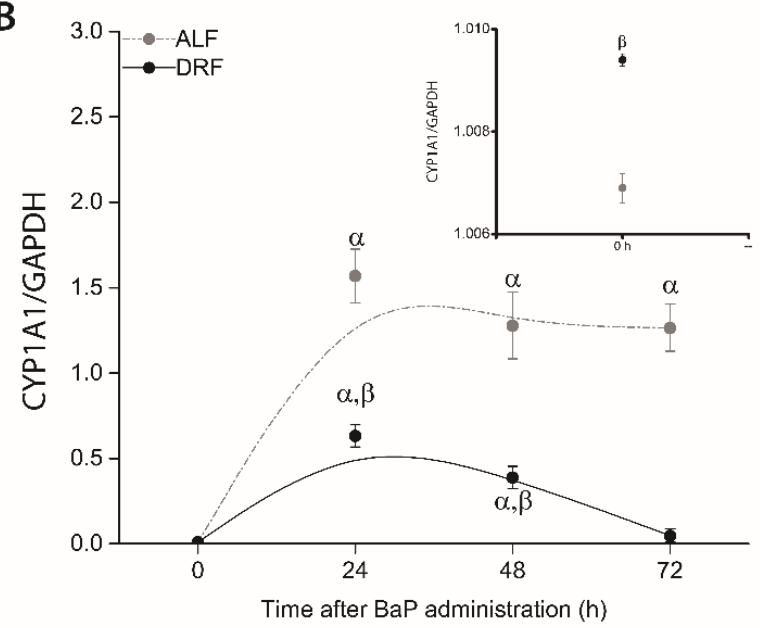

D

ALF

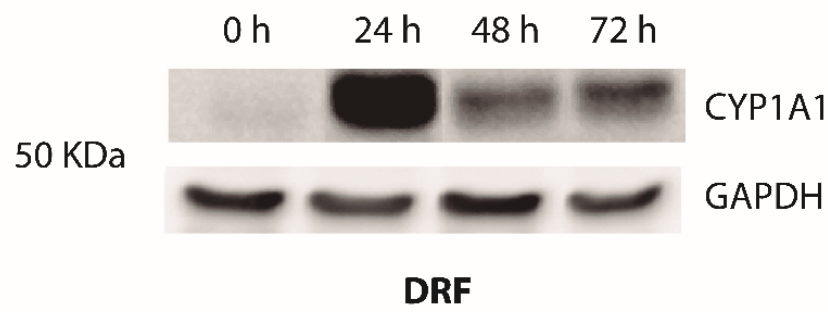

$0 \mathrm{~h} \quad 24 \mathrm{~h} \quad 48 \mathrm{~h} \quad 72 \mathrm{~h}$

CYP1A1

$50 \mathrm{KDa}$

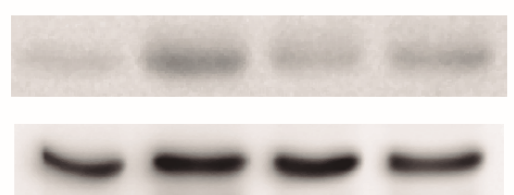

GAPDH

Figure 2. mRNA (A), protein levels (B,D), and activity of CYP1A1 (C) in the livers of rats in the ALF (gray circles) and DRF (black circles) groups after $10 \mathrm{mg} / \mathrm{Kg} \mathrm{BaP}$ administration. Values correspond to the mean $\pm \mathrm{SEM}, n=6 . \alpha p \leq 0.05$ compared to the control group with the same diet (DRF at ZT1 and ALF at ZT13) and $\beta p \leq 0.05$ compared to the ALF group at the same time points.

In the group with DRF, CYP1A1 mRNA levels were increased 24-fold at $24 \mathrm{~h}$ after BaP administration ( $p \leq 0.05$, compared with the DRF control group), but they were 5.72-fold lower than the ALF group at $24 \mathrm{~h}(p \leq 0.05)$ and they decreased to the basal expression levels $48 \mathrm{~h}$ later. CYP1A1 protein levels were increased 109- and 41-fold at 24 and $48 \mathrm{~h}$ respectively, after BaP administration ( $p \leq 0.05$, compared with the DRF control group), but they were 2.4- and 3.2-fold lower than the ALF group at 24 and $48 \mathrm{~h}$ respectively, after $\mathrm{BaP}$ administration $(p \leq 0.05)$. CYP1A1 activity was increased 3.37- and 2.01-fold at 24 and $48 \mathrm{~h}$ respectively, after BaP administration $(p \leq 0.05$, compared with the DRF control group), but it was 3.05- and 4.14-fold lower than the ALF group at 24 and $48 \mathrm{~h}$, respectively 
$(p \leq 0.05)$. Vehicle control groups (rats under ALF or DRF administrated with only corn oil) did not show a difference between ALF and DRF (Table 3).

Table 3. Effect of vehicle (corn oil) administrated i.p. in rats during ALF or DRF protocol on the expression/activity of CYP1A1, and transaminase serum activities.

\begin{tabular}{ccccc}
\hline & \multicolumn{2}{c}{ Control } & \multicolumn{2}{c}{ Only Corn Oil } \\
\cline { 2 - 5 } & ALF & DRF & ALF & DRF \\
\hline $\begin{array}{c}\text { CYP1A1/RPS18 } \\
\text { CYP1A1 activity } \\
\text { ALT }\end{array}$ & $0.0043 \pm 0.0003$ & $0.0400 \pm 0.002$ & $0.0046 \pm 0.0010$ & $0.0394 \pm 0.005$ \\
\hline $\begin{array}{c}\left.\text { pMol resorufin } \times \text { mg protein } \times \mathrm{min}^{-1}\right) \\
\mathrm{U} / \mathrm{m} \text { protein }\end{array}$ & $0.0069 \pm 0.0002$ & $0.0094 \pm 0.0001$ & $0.0067 \pm 0.0001$ & $0.0096 \pm 0.0001$ \\
\hline $\begin{array}{c}\text { AST } \\
\mathrm{U} / \mathrm{m} \text { protein }\end{array}$ & $106.3 \pm 1.91$ & $141 \pm 2.8$ & $106.7 \pm 2.61$ & $140 \pm 5.8$ \\
\hline
\end{tabular}

Each data point corresponds to the mean \pm SEM, $n=6$.

\subsection{DRF Attenuated BPDE-DNA Adduct Levels in the Liver}

In rats with ALF, the maximum accumulation of BPDE-DNA adducts (0.41843 adducts/ $10^{8}$ nucleotides) was observed $48 \mathrm{~h}$ after BaP injection (Figure 3). In rats with DRF, BPDEDNA adduct levels were 0.08821 adducts $/ 10^{8}$ nucleotides at $48 \mathrm{~h}, 4.74$-fold lower than the ALF group at the same time $(p \leq 0.05)$ (Figure $3 \mathrm{~A})$. To determine if the decrease in BPDE-DNA adducts observed at $48 \mathrm{~h}$ in the DRF group was also observed at different concentrations of $\mathrm{BaP}$, we evaluated the levels of BPDE-DNA adducts at three different concentrations of $\mathrm{BaP}(10,50$, and $100 \mathrm{mg} / \mathrm{kg})$. The rats exposed to $50 \mathrm{mg} / \mathrm{kg} \mathrm{BaP}$ in the DRF group showed decreased (1.4-fold) levels of BPDE-DNA adducts ( $p \leq 0.05$, compared with the ALF group), while the rats exposed to $100 \mathrm{mg} / \mathrm{kg} \mathrm{BaP} \mathrm{did} \mathrm{not} \mathrm{show} \mathrm{a} \mathrm{difference.}$ (Figure 3B).

A

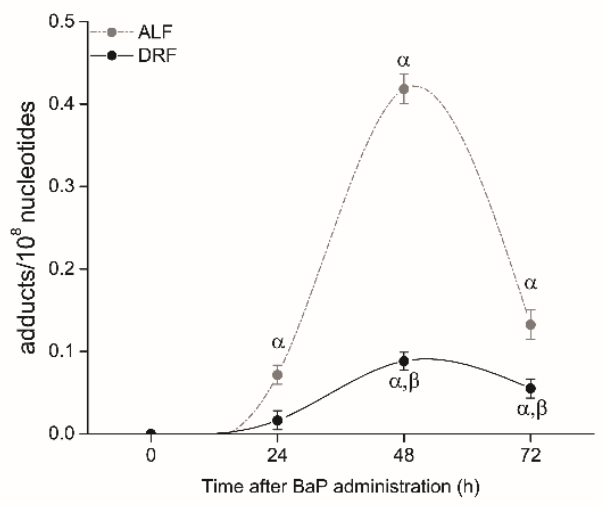

B

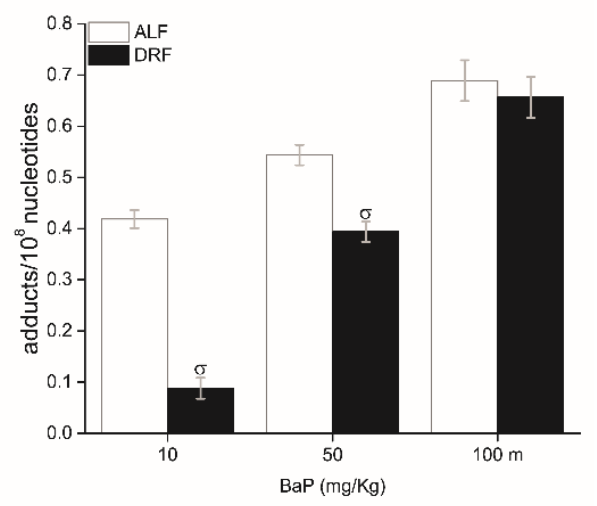

Figure 3. BPDE-DNA adduct levels in the liver of rats with ALF (gray circles) and DRF (black circles) after BaP administration at $10 \mathrm{mg} / \mathrm{kg}$ (A). BPDE-DNA adduct levels in the liver of rats with ALF (white bar) and DRF (black bar) after BaP administration at 10,50, or $100 \mathrm{mg} / \mathrm{kg}(\mathbf{B})$. Each point corresponds to the mean $\pm \mathrm{SEM}, n=6 . \alpha p \leq 0.05$ compared to the control group that was fed with the same diet (DRF at ZT1 and ALF at ZT13), $\beta p \leq 0.05$ compared to the ALF group at the same time point, and $\sigma p \leq 0.05$ compared to the ALF group treated with the same concentrations of BaP.

\subsection{DRF Attenuated Serum AST and ALT Activities after BaP Exposure}

In rats under ALF, ALT and AST activities were increased at 24 (2.5-fold) and $48 \mathrm{~h}$ (2.13-fold) after BaP exposure respectively, and were maintained higher than ALF control until $72 \mathrm{~h}(p \leq 0.05)$ (Figure 4A,B). After BaP injection, rats with DRF qualitatively showed the same pattern in animals under ALF with respect to AST, but with minor intensity 
(increased 2.13-fold at $48 \mathrm{~h}, p \leq 0.05$, compared with the control group, and decreased at $72 \mathrm{~h}$ ). Nevertheless, ALT activity in the DRF group decreased 5.5-fold at $24 \mathrm{~h}$ and was maintained lower than the control until $72 \mathrm{~h}(p \leq 0.05)$ (Figure 4A,B). Vehicle control groups (rats under ALF or DRF administrated only with corn oil) did not show a difference between ALF and DRF (Table 3).

A

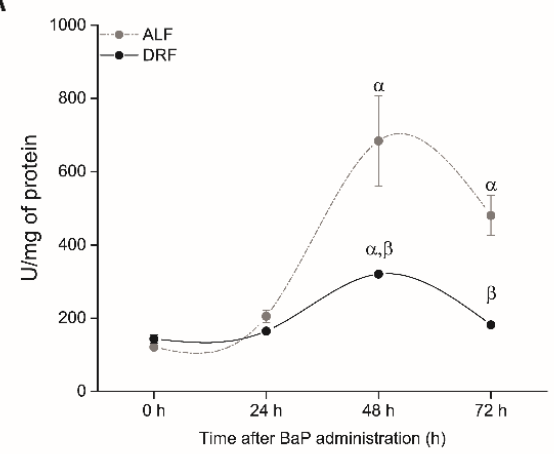

B

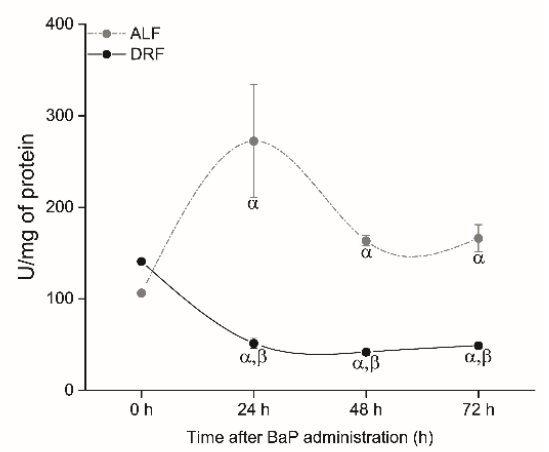

Figure 4. Activities of AST (A) and ALT (B) in the blood of rats with ALF (gray circles) and DRF (black circles) after BaP administration at $10 \mathrm{mg} / \mathrm{kg}$. Each point corresponds to the mean $\pm \mathrm{SEM}, n=6 . \alpha p \leq 0.05$ compared to the control group fed with the same diet (DRF at ZT1 and ALF at ZT13) and $\beta p \leq 0.05$ compared to the ALF group at the same time points.

\subsection{BaP Retention in the Liver}

In rats under ALF, maximal unmetabolized $\mathrm{BaP}$ retention (14.7 $\mathrm{pMol} \mathrm{BaP} / \mathrm{g}$ of liver) was observed at $24 \mathrm{~h}$ after $\mathrm{BaP}$ administration, and decreased at subsequent times recorded (Figure 5). In rats with DRF, we observed a 5.4-fold decrease in unmetabolized BaP retention at $24 \mathrm{~h}$ ( $p \leq 0.05$, compared to the ALF group at the same time point), which decreased at subsequent times recorded (Figure 5). It is worthy to note that the liver concentration of total unmetabolized $\mathrm{BaP}$ at $24 \mathrm{~h}$ was lower in the DRF group than in the ALF group of animals.

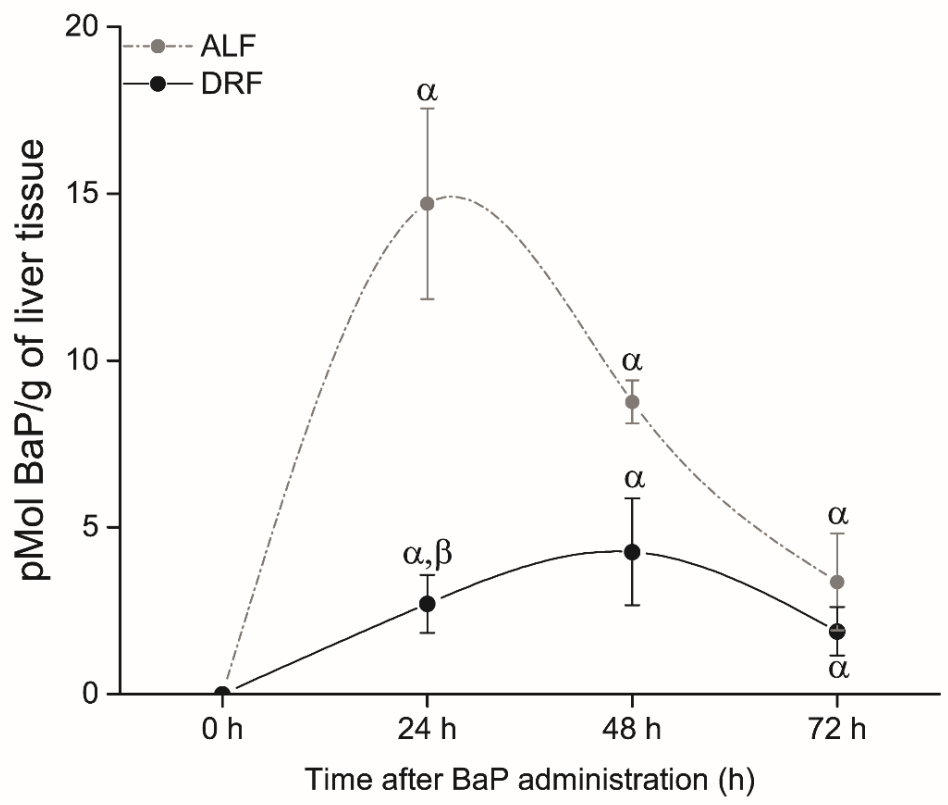

Figure 5. Retention of unmetabolized $\mathrm{BaP}$ in the liver of rats with ALF (gray circles) and DRF (black circles) after $\mathrm{BaP}$ administration at $10 \mathrm{mg} / \mathrm{kg}$. Each point corresponds to the mean $\pm \mathrm{SEM}, n=6$. $\alpha p \leq 0.05$ compared to the control group fed with the same diet (DRF at ZT1 and ALF at ZT13) and $\beta p \leq 0.05$ compared to the ALF group at the same time point. 


\section{Discussion}

In rats under ALF, the SCN controls behavioral and physiological rhythms. Nevertheless, when the food availability is restricted to a specific and shorter-than-usual time at a particular time each day (DRF protocol), rats show a second period of arousal and increased locomotor activity that occurs before the time of the daily mealtime (called foodanticipatory activity), which is independent of signaling by the SCN [34]. Moreover, in the liver, clock genes such as Bmal1, Per1, and Per2 modify their temporal pattern [35,36], and enzymes involved in nutrients and xenobiotics metabolism are modified according to the mealtime [34].

The genes modulated by the clock genes have one or more consensus-binding sites for the molecular clock (E-box) in their promoter region [37]. The AhR promoter has an E-box ${ }^{11}$, and this could be responsible for its temporal variation observed in both the ALF and DRF groups (Figure 1A), and in previous reports by others [10]. One peak of maximal expression was observed in both groups of rats at the same time (ZT14). The AhR promoter contains a glucocorticoid-responsive element, as well as others such as cAMP-, antioxidant-, and dioxin-responsive elements [38,39], suggesting that the AhR expression depends on more than one factor to promote its transcription.

In rats under ALF, ARNT shows a peak of higher expression at ZT17 (Figure 1B), and this could be due to the positive modulation by albumin D-element binding protein (DBP) that shows temporal variation with a peak in the early night [40]. During the restricted feeding protocol, the temporal pattern in DBP is modified in the liver, increasing during the light phase (mealtime) but decreasing in the night phase [41], as ARNT expression is BDPdependent, and this could be a possible factor involved in the almost similar expression of $A R N T$ throughout the $24 \mathrm{~h}$ time period in DRF rats (Figure 1B).

CYP1A1 has shown variations during a $24 \mathrm{~h}$ period in the liver, lung, and $\mathrm{SCN}[11,42]$ that coincide with the period of highest food consumption [23]. Through food, ingested compounds may activate the AhR pathway, inducing CYP1A1 expression [43], suggesting that CYP1A1 increase could be related to food access. Therefore, we modified food access to $2 \mathrm{~h}$ per day in the light period (ZT4 to ZT6) for 21 days, promoting an increase in CYP1A1 expression before the mealtime. These results suggest that modification of CYP1A1 expression is associated with constant fasting/feeding cycles, and there are at least two possible explanations for these data. First, an endogenous ligand that increases during the time before mealtime may activate AhR, leading to CYP1A1 mRNA induction, where multiple potential ligands to AhR such as tryptophan metabolites, heme metabolites, and arachidonic acid metabolites have been proposed [43]. Second, a non-canonical mechanism mediated by kinase activity induces CYP1A1 [44].

Previous reports have shown that rats with acute-fasting increased IL- $1 \alpha$, IL- 6 , and TNF- $\alpha$ [36], enzymes involved in gluconeogenesis (G6pasa PEPCK) [17], ketonic bodies, and sirtuin [16]. However, our results showed that $A h R, A R N T$, and CYP1A1 expression were not modified during acute-fasting (Fa group) or acute-fasting and $2 \mathrm{~h}$ refeeding ( $\mathrm{Re}$ group). These results suggest that the observed effect in these genes is due to constant fasting/refeeding cycles.

PAHs have been classified as human carcinogens by the International Agency for Research on Cancer (IARC) [45]. BaP is the most studied PAH and is considered a model compound that can be metabolized by CYP1A1, contributing to $48.3 \%$ of BPDE, the ultimate reactive species that can react with DNA, promoting mutagenic and carcinogenic processes. Additionally, other CYPs, such as CYP1B1, CYP3A4, and CYP2C19 [46], and cytosolic enzymes such as 5-lipoxygenase or cyclooxygenase $1 / 2$, are able to participate to a lesser extent than CYP1A1 in the bioactivation of $\mathrm{BaP}$ [47].

In regard to the CYP1A1 induction property of $\mathrm{BaP}, C Y P 1 A 1$ expression and protein concentration and activity in the DRF group were lower than that observed in the ALF group (Figure 2). As reported by others [48-51], the single i.p. administration of BaP to rats with free access to water and food produced the maximal levels of BPDE-DNA adducts two days after administration, and they decayed at $72 \mathrm{~h}$. In the case of rats under DRF, 
at $48 \mathrm{~h}$ after BaP administration, the levels of BPDE-DNA adducts were lower than those found in animals under ALF (Figure 3A). This protective effect is also observed in rats under DRF that received $50 \mathrm{mg} / \mathrm{kg}$ BaP compared with rats under ALF (Figure 3), which coincided with a low CYP1A1 activity in rats under DRF (data not shown).

BaP toxicity is not limited to DNA damage since it was associated to an increased serum AST and ALT, suggesting acute liver necrotic activity [52,53]. We found that AST activity was less increased in the DRF group compared to ALF, and ALT activity was decreased (Figure 4). These results may also be related to a decrease in the metabolism of BaP due to a less increased induction and activity of CYP1A1 after BaP administration (Figure 2). This assumption is supported by the fact that the protective effect of DRF against genotoxicity is minimized in a dose-related way if the used BaP concentrations are increased (Figure 3B).

DRF is a protocol that includes two features: (a) a decreased caloric intake and (b) periodicity in food availability [54]. Previous reports show that a low caloric intake contributes to longevity and multiple health benefits [55], however, it increases basal CYP1A1 activity (but with no changes in its temporal pattern) [56], promoting increases in BPDE-DNA adducts [57]. The differences between the above findings and our results are evidence to support that DRF and caloric restriction regulate different metabolic pathways [54].

We cannot rule out that there may be additional mechanisms involved in DRFmediated protection. Previous reports show that DRF modifies the valproic acid concentration, absorption, and pharmacokinetics during mealtime [58-60], and decreases gentamicin bioaccumulation [19]. Due to the heterogeneity in the chemical structure of the above-mentioned xenobiotics, we suggest that a process associated with fasting/feeding cycles may be involved. A possible candidate process is blood flow, since it was observed that it influences drug absorption, metabolism, excretion, and blood flow to the enteric system increases during mealtime [60-63]. Additionally, DRF modifies renal excretion [64]. An alternative/additional hypothesis is that during DRF, heart rate and blood pressure show an acute increase in the period before food access, favoring mobilization of BaP (and other xenobiotics) outside the liver and promoting their excretion, as observed in the case of methotrexate [65]. Concerning this matter, we found that DRF decreases BaP retention in the liver, which was correlated with low liver CYP1A1 levels and BPDE-DNA adducts as well as diminished transaminases activity in the blood. These results suggest that the reduction of $\mathrm{BaP}$ retention during DRF could be an additional factor in the attenuation of BaP liver genotoxicity.

We do not discard that some endogenous, weak AhR ligands (indigoids, heme metabolites, eicosanoid, or equilenin) [66] could interfere with the CYP-induction properties of $\mathrm{BaP}$, as observed with natural compounds such as quercetin or kaempferol [67].

In this study, we presented evidence that DRF increases CYP1A1 expression during the time before food intake but decreases the CYP1A1 induction potency of BaP when the xenobiotic is administered before the CYP1A1 acrophase. Additionally, rats under DRF are resistant to liver toxicity by $\mathrm{BaP}$ as BPDE-DNA adducts and AST and ALT activities are lower than those observed in ALF rats. The time-lag between AhR and ARNT acrophase caused by DRF may be partly responsible for these results, although additional physiological factors leading to poor liver retention of unmetabolized BaP could also be involved. Finally, we cannot exclude the possibility that $\mathrm{BaP}$ administration at different times in the ALF and DRF groups may influence the obtained results.

Author Contributions: Conceptualization, O.S.Á.-R., M.D.-M., R.C.-C. and J.J.E.-A.; Formal analysis, O.S.Á.-R., M.D.-M. and J.J.E.-A.; Investigation, O.S.Á.-R., M.D.-M., R.C.-C., E.C.-U., J.P.-C. and J.J.E.A.; Methodology, E.C.-U., J.P.-C., J.O.G.-R. and J.J.E.-A.; Project administration, J.J.E.-A.; Supervision, E.C.-U., J.P.-C., J.O.G.-R. and J.J.E.-A.; Writing-original draft, O.S.Á.-R., M.D.-M., R.C.-C. and J.J.E.-A. All authors have read and agreed to the published version of the manuscript.

Funding: This research received no external funding. 
Institutional Review Board Statement: All experimental procedures were approved and conducted according to the institutional guide for the care and use of animals under biomedical experimentation (Neurobiology Institute, National Autonomous University of Mexico), under the protocol \#33 ratified by the Bioethical Committee of Neurobiology Institute (September 2006).

Informed Consent Statement: Not applicable.

Data Availability Statement: Data is contained within the article.

Acknowledgments: Oscar Samuel Ávila Rosales was supported by a CONACYT (Consejo Nacional de Ciencia y Tecnología) fellowship No. 619803 to study in the program: Programa de Maestría y Doctorado en Ciencias Bioquímicas at Universidad Nacional Autónoma de México. We thank Hernández-Ojeda Sandra Luz, Elinos Martha, and Serrano-García Luis for their excellent technical assistance. We also want to thank Navarro-Mabarak Cynthia for the grammatical review of this manuscript.

Conflicts of Interest: The authors declare that they have no known competing financial interests or personal relationships that could have influenced the work reported in this paper.

\section{References}

1. Wang, Z.; Yang, P.; Xie, J.; Lin, H.-P.; Kumagai, K.; Harkema, J.; Yang, C. Arsenic and benzo[a]pyrene co-exposure acts synergistically in inducing cancer stem cell-like property and tumorigenesis by epigenetically down-regulating SOCS3 expression. Environ. Int. 2020, 137, 105560. [CrossRef]

2. Degrendele, C.; Audy, O.; Hofman, J.; Kučerik, J.; Kukucka, P.; Mulder, M.D.; Přibylová, P.; Prokeš, R.; Šáňka, M.; Schaumann, G.E.; et al. Diurnal Variations of Air-Soil Exchange of Semivolatile Organic Compounds (PAHs, PCBs, OCPs, and PBDEs) in a Central European Receptor Area. Environ. Sci. Technol. 2016, 50, 4278-4288. [CrossRef]

3. Hecht, S.S. Tobacco smoke carcinogens and lung cancer. J. Natl. Cancer Inst. 1999, 91, 1194-1210. [CrossRef] [PubMed]

4. Hayakawa, K. Environmental Behaviors and Toxicities of Polycyclic Aromatic Hydrocarbons and Nitropolycyclic Aromatic Hydrocarbons. Chem. Pharm. Bull. 2016, 64, 83-94. [CrossRef] [PubMed]

5. Kawajiri, K.; Fujii-Kuriyama, Y. Cytochrome P450 gene regulation and physiological functions mediated by the aryl hydrocarbon receptor. Arch. Biochem. Biophys. 2007, 464, 207-212. [CrossRef] [PubMed]

6. Ewa, B.; Danuta, M.Š. Polycyclic aromatic hydrocarbons and PAH-related DNA adducts. J. Appl. Genet. 2017, 58, 321-330. [CrossRef] [PubMed]

7. Lee, H.M.; Chae, Y.H.; Kwon, C.; Kim, S.K. Conformations of adducts formed between the genotoxic benzo[a]pyrene-7,8-dione and nucleosides studied by density functional theory. Biophys. Chem. 2007, 125, 151-158. [CrossRef] [PubMed]

8. Shimada, T.; Fujii-Kuriyama, Y. Metabolic activation of polycyclic aromatic hydrocarbons to carcinogens by cytochromes $\mathrm{P} 450$ 1A1 and 1B1. Cancer Sci. 2004, 95, 1-6. [CrossRef]

9. Verma, N.; Pink, M.; Rettenmeier, A.W.; Schmitz-Spanke, S. Review on proteomic analyses of benzo[a]pyrene toxicity. Proteomics 2012, 12, 1731-1755. [CrossRef] [PubMed]

10. Richardson, V.M.; Santostefano, M.J.; Birnbaum, L.S. Daily cycle of bHLH-PAS proteins, Ah receptor and Arnt, in multiple tissues of female Sprague-Dawley rats. Biochem. Biophys. Res. Commun. 1998, 252, 225-231. [CrossRef]

11. Tanimura, N.; Kusunose, N.; Matsunaga, N.; Koyanagi, S.; Ohdo, S. Aryl hydrocarbon receptor-mediated Cyp1a1 expression is modulated in a CLOCK-dependent circadian manner. Toxicology 2011, 290, 203-207. [CrossRef]

12. Zmrzljak, U.P.; Rozman, D. Circadian regulation of the hepatic endobiotic and xenobitoic detoxification pathways: The time matters. Chem. Res. Toxicol. 2012, 25, 811-824. [CrossRef] [PubMed]

13. Hirota, T.; Fukada, Y. Resetting mechanism of central and peripheral circadian clocks in mammals. Zoolog. Sci. 2004, 21, 359-368. [CrossRef] [PubMed]

14. Cassone, V.M.; Stephan, F.K. Central and peripheral regulation of feeding and nutrition by the mammalian circadian clock: Implications for nutrition during manned space flight. Nutrition 2002, 18, 814-819. [CrossRef]

15. Hirao, J.; Arakawa, S.; Watanabe, K.; Ito, K.; Furukawa, T. Effects of restricted feeding on daily fluctuations of hepatic functions including p450 monooxygenase activities in rats. J. Biol. Chem. 2006, 281, 3165-3171. [CrossRef]

16. Rivera-Zavala, J.B.; Molina-Aguilar, C.; Pérez-Mendoza, M.; Olguín-Martínez, M.; Hernández-Muñoz, R.; Báez-Ruiz, G.A.; Díaz-Muñoz, M. Daytime restricted feeding modifies the daily regulation of fatty acid $\beta$-oxidation and the lipoprotein profile in rats. Br. J. Nutr. 2017, 117, 930-941. [CrossRef] [PubMed]

17. Pérez-Mendoza, M.; Rivera-Zavala, J.B.; Díaz-Muñoz, M. Daytime restricted feeding modifies the daily variations of liver gluconeogenesis: Adaptations in biochemical and endocrine regulators. Chronobiol. Int. 2014, 31, 815-828. [CrossRef]

18. Luna-Moreno, D.; García-Ayala, B.; Díaz-Muñoz, M. Daytime restricted feeding modifies 24 h rhythmicity and subcellular distribution of liver glucocorticoid receptor and the urea cycle in rat liver. Br. J. Nutr. 2012, 108, 2002-2013. [CrossRef] [PubMed]

19. Beauchamp, D.; Guimont, C.; Grenier, L.; Lebrun, M.; Tardif, D.; Gourde, P.; Bergeron, M.G.; Thibault, L.; Labrecque, G. Timerestricted feeding schedules modify temporal variation of gentamicin experimental nephrotoxicity. Antimicrob. Agents Chemother. 1997, 41, 1468-1474. [CrossRef] 
20. Matsunaga, N.; Nakamura, N.; Yoneda, N.; Qin, T.; Terazono, H.; To, H.; Higuchi, S.; Ohdo, S. Influence of feeding schedule on 24-h rhythm of hepatotoxicity induced by acetaminophen in mice. J. Pharmacol. Exp. Ther. 2004, 311, 594-600. [CrossRef]

21. Molina-Aguilar, C.; Guerrero-Carrillo, M.D.J.; Espinosa-Aguirre, J.J.; Olguin-Reyes, S.; Castro-Belio, T.; Vázquez-Martínez, O.; Rivera-Zavala, J.B.; Díaz-Muñoz, M. Time-caloric restriction inhibits the neoplastic transformation of cirrhotic liver in rats treated with diethylnitrosamine. Carcinogenesis 2017, 38, 847-858. [CrossRef] [PubMed]

22. Yan, L.; Sundaram, S.; Mehus, A.A.; Picklo, M.J. Time-restricted Feeding Attenuates High-fat Diet-enhanced Spontaneous Metastasis of Lewis Lung Carcinoma in Mice. Anticancer Res. 2019, 39, 1739-1748. [CrossRef] [PubMed]

23. Portaluppi, F.; Touitou, Y.; Smolensky, M.H. Ethical and methodological standards for laboratory and medical biological rhythm research. Chronobiol. Int. 2008, 25, 999-1016. [CrossRef] [PubMed]

24. Claassen, V. Intraperitoneal Drug Administration, Techniques in the Behavioral and Neural Sciences. In Neglected Factors in Pharmacology and Neuroscience Research: Biopharmaceutics, Animal Characteristics, Maintenance, Testing Conditions; Claassen, V., Ed.; Elsevier: Amsterdam, The Netherlands, 1994; Volume 12. [CrossRef]

25. Chomczynski, P.; Sacchi, N. The single-step method of RNA isolation by acid guanidinium thiocyanate-phenol-chloroform extraction: Twenty-something years on. Nat. Protoc. 2006, 1, 581-585. [CrossRef] [PubMed]

26. Livak, K.J.; Schmittgen, T.D. Analysis of relative gene expression data using real-time quantitative PCR and the 2(-Delta Delta C(T)) Method. Methods 2001, 25, 402-408. [CrossRef]

27. Bradford, M.M. A rapid and sensitive method for the quantitation of microgram quantities of protein utilizing the principle of protein-dye binding. Anal. Biochem. 1976, 72, 248-254. [CrossRef]

28. Burke, M.D.; Thompson, S.; Weaver, R.J.; Wolf, C.R.; Mayer, R.T. Cytochrome P450 specificities of alkoxyresorufin O-dealkylation in human and rat liver. Biochem. Pharmacol. 1994, 48, 923-936. [CrossRef]

29. Jee, S.C.; Kim, M.; Sung, J.S. Modulatory Effects of Silymarin on Benzo[a]pyrene-Induced Hepatotoxicity. Int. J. Mol. Sci. 2020, 21, 2369. [CrossRef]

30. Wang, C.H.; Wu, S.H.; Zhou, S.L.; Shi, Y.X.; Song, J. Characteristics and source indentification of polycyclic aromatic hydrocarbons (PAHs) in urban soils: A review. Pedosphere 2017, 27, 17-26. [CrossRef]

31. Bergmeyer, H.U.; Scheibe, P.; Wahlefeld, A.W. Optimization of methods for aspartate aminotransferase and alanine aminotransferase. Clin. Chem. 1978, 24, 58-73. [CrossRef]

32. Vega-López, A.; Ayala-López, G.; Posadas-Espadas, B.P.; Olivares-Rubio, H.F.; Dzul-Caamal, R. Relations of oxidative stress in freshwater phytoplankton with heavy metals and polycyclic aromatic hydrocarbons. Comp. Biochem. Physiol. Part A Mol. Integr. Physiol. 2013, 165, 498-507. [CrossRef]

33. Refinetti, R.; Lissen, G.C.; Halberg, F. Procedures for numerical analysis of circadian rhythms. Biol. Rhythm. Res. 2007, 38, 275-325. [CrossRef] [PubMed]

34. Aguilar-Roblero, R.; Díaz-Muñoz, M. Chronostatic adaptations in the liver to restricted feeding: The FEO as an emergent oscillator. Sleep Biol. Rhythms. 2010, 8, 9-17. [CrossRef]

35. Arellanes-Licea Edel, C.; Báez-Ruiz, A.; Carranza, M.E.; Arámburo, C.; Luna, M.; Díaz-Muñoz, M. Daily patterns and adaptation of the ghrelin, growth hormone and insulin-like growth factor-1 system under daytime food synchronisation in rats. $J$. Neuroendocrinol. 2014, 26, 282-295. [CrossRef] [PubMed]

36. Luna-Moreno, D.; Aguilar-Roblero, R.; Díaz-Muñoz, M. Restricted feeding entrains rhythms of inflammation-related factors without promoting an acute-phase response. Chronobiol. Int. 2009, 26, 1409-1429. [CrossRef] [PubMed]

37. Westermark, P.O.; Herzel, H. Mechanism for $12 \mathrm{hr}$ rhythm generation by the circadian clock. Cell Rep. 2013, 3, 1228-1238. [CrossRef] [PubMed]

38. Garrison, P.M.; Denison, M.S. Analysis of the murine AhR gene promoter. J. Biochem. Mol. Toxicol. 2000, 14, 1-10. [CrossRef]

39. Shin, S.; Wakabayashi, N.; Misra, V.; Biswal, S.; Lee, G.H.; Agoston, E.S.; Yamamoto, M.; Kensler, T.W. NRF2 modulates aryl hydrocarbon receptor signaling: Influence on adipogenesis. Mol. Cell Biol. 2007, 27, 7188-7197. [CrossRef] [PubMed]

40. Nakabayashi, H.; Ohta, Y.; Yamamoto, M.; Susuki, Y.; Taguchi, A.; Tanabe, K.; Kondo, M.; Hatanaka, M.; Nagao, Y.; Tanizawa, Y. Clock-controlled output gene Dbp is a regulator of Arnt/Hif- $1 \beta$ gene expression in pancreatic islet $\beta$-cells. Biochem. Biophys. Res. Commun. 2013, 434, 370-375. [CrossRef]

41. Damiola, F.; Le Minh, N.; Preitner, N.; Kornmann, B.; Fleury-Olela, F.; Schibler, U. Restricted feeding uncouples circadian oscillators in peripheral tissues from the central pacemaker in the suprachiasmatic nucleus. Genes Dev. 2000, 14, $2950-2961$. [CrossRef]

42. Mukai, M.; Lin, T.M.; Peterson, R.E.; Cooke, P.S.; Tischkau, S.A. Behavioral rhythmicity of mice lacking AhR and attenuation of light-induced phase shift by 2,3,7,8-tetrachlorodibenzo-p-dioxin. J. Biol. Rhythms. 2008, 23, 200-210. [CrossRef] [PubMed]

43. Nguyen, L.P.; Bradfield, C.A. The search for endogenous activators of the aryl hydrocarbon receptor. Chem. Res. Toxicol. 2008, 21, 102-116. [CrossRef] [PubMed]

44. Pallotta, M.T.; Fallarino, F.; Matino, D.; Macchiarulo, A.; Orabona, C. AhR-Mediated, Non-Genomic Modulation of IDO1 Function. Front. Immunol. 2014, 5, 497. [CrossRef] [PubMed]

45. IARC Working Group on the Evaluation of Carcinogenic Risks to Humans. Some non-heterocyclic polycyclic aromatic hydrocarbons and some related exposures. IARC Monogr. Eval. Carcinog. Risks Hum. 2010, 92, 1-853. 
46. Šulc, M.; Indra, R.; Moserová, M.; Schmeiser, H.H.; Frei, E.; Arlt, V.M.; Stiborová, M.; White, P. The impact of individual cytochrome P450 enzymes on oxidative metabolism of benzo[a]pyrene in human livers. Environ. Mol. Mutagen. 2016, 57, 229-235. [CrossRef]

47. Wang, L.; Xu, W.; Ma, L.; Zhang, S.; Zhang, K.; Ye, P.; Xing, G.; Zhang, X.; Cao, Y.; Xi, J.; et al. Detoxification of benzo[a]pyrene primarily depends on cytochrome P450, while bioactivation involves additional oxidoreductases including 5-lipoxygenase, cyclooxygenase, and aldo-keto reductase in the liver. J. Biochem. Mol. Toxicol. 2017, 31, e21902. [CrossRef]

48. Stowers, S.J.; Anderson, M.W. Formation and persistence of benzo(a)pyrene metabolite-DNA adducts. Environ. Health Perspect. 1985, 62, 31-39. [CrossRef]

49. Nesnow, S.; Ross, J.; Nelson, G.; Holden, K.; Erexson, G.; Kligerman, A.; Gupta, R.C. Quantitative and temporal relationships between DNA adduct formation in target and surrogate tissues: Implications for biomonitoring. Environ. Health Perspect. 1993, 101 (Suppl. 3), 37-42. [CrossRef] [PubMed]

50. Kim, H.S.; Lee, B.M. Inhibition of benzo[a]pyrene-DNA adduct formation by Aloe barbadensis Miller. Carcinogenesis 1997, 18, 771-776. [CrossRef]

51. Godschalk, R.W.; Moonen, E.J.; Schilderman, P.A.; Broekmans, W.M.; Kleinjans, J.C.; Van Schooten, F.J. Exposure-route-dependent DNA adduct formation by polycyclic aromatic hydrocarbons. Carcinogenesis 2000, 21, 87-92. [CrossRef]

52. Uno, S.; Dalton, T.P.; Dragin, N.; Curran, C.P.; Derkenne, S.; Miller, M.L.; Shertzer, H.G.; Gonzalez, F.J.; Nebert, D.W. Oral benzo[a]pyrene in Cyp1 knockout mouse lines: CYP1A1 important in detoxication, CYP1B1 metabolism required for immune damage independent of total-body burden and clearance rate. Mol. Pharmacol. 2006, 69, 1103-1114. [CrossRef] [PubMed]

53. Shi, Z.; Dragin, N.; Gálvez-Peralta, M.; Jorge-Nebert, L.F.; Miller, M.L.; Wang, B.; Nebert, D.W. Organ-specific roles of CYP1A1 during detoxication of dietary benzo[a]pyrene. Mol. Pharmacol. 2010, 78, 46-57. [CrossRef] [PubMed]

54. Patel, S.A.; Velingkaar, N.; Makwana, K.; Chaudhari, A.; Kondratov, R. Calorie restriction regulates circadian clock gene expression through BMAL1 dependent and independent mechanisms. Sci. Rep. 2016, 6, 25970. [CrossRef] [PubMed]

55. Froy, O. Circadian rhythms, aging, and life span in mammals. Physiology 2011, 26, 225-235. [CrossRef] [PubMed]

56. Manjgaladze, M.; Chen, S.; Frame, L.T.; Seng, J.E.; Duffy, P.H.; Feuers, R.J.; Hart, R.W.; Leakey, J.E. Effects of caloric restriction on rodent drug and carcinogen metabolizing enzymes: Implications for mutagenesis and cancer. Mutat. Res. 1993, 295, 201-222. [CrossRef]

57. Chou, M.W.; Kong, J.; Chung, K.T.; Hart, R.W. Effect of caloric restriction on the metabolic activation of xenobiotics. Mutat. Res. 1993, 295, 223-235. [CrossRef]

58. Ohdo, S.; Nakano, S.; Ogawa, N. Chronopharmacokinetics of valproic acid following constant-rate administration in mice. Chronobiol. Int. 1991, 8, 35-43. [CrossRef]

59. Song, J.G.; Ohdo, S.; Ogawa, N. Chronopharmacokinetics of valproic acid following constant-rate administration in mice and influence of feeding schedule. Zhongguo Yao Li Xue Bao Acta Pharmacol. Sin. 1995, 16, 113-117.

60. Ohdo, S.; Ogawa, N.; Nakano, S.; Higuchi, S. Influence of feeding schedule on the chronopharmacological aspects of sodium valproate in mice. J. Pharmacol. Exp. Ther. 1996, 278, 74-81.

61. Van den Buuse, M. Circadian rhythms of blood pressure and heart rate in conscious rats: Effects of light cycle shift and timed feeding. Physiol. Behav. 1999, 68, 9-15. [CrossRef]

62. Sutton, E.F.; Beyl, R.; Early, K.S.; Cefalu, W.T.; Ravussin, E.; Peterson, C.M. Early Time-Restricted Feeding Improves Insulin Sensitivity, Blood Pressure, and Oxidative Stress Even without Weight Loss in Men with Prediabetes. Cell Metab. 2018, 27, 1212-1221.e3. [CrossRef] [PubMed]

63. Boulamery-Velly, A.; Simon, N.; Vidal, J.; Mouchet, J.; Bruguerolle, B. Effects of three-hour restricted food access during the light period on circadian rhythms of temperature, locomotor activity, and heart rate in rats. Chronobiol. Int. 2005, 22, 489-498. [CrossRef]

64. Engin, A. Circadian Rhythms in Diet-Induced Obesity. Adv. Exp. Med. Biol. 2017, 960, 19-52. [CrossRef] [PubMed]

65. Song, J.G.; Nakano, S.; Ohdo, S.; Ogawa, N. Chronotoxicity and chronopharmacokinetics of methotrexate in mice: Modification by feeding schedule. Jpn. J. Pharmacol. 1993, 62, 373-378. [CrossRef] [PubMed]

66. Stejskalova, L.; Dvorak, Z.; Pavek, P. Endogenous and exogenous ligands of aryl hydrocarbon receptor: Current state of art. Curr. Drug Metab. 2011, 12, 198-212. [CrossRef] [PubMed]

67. Niestroy, J.; Barbara, A.; Herbst, K.; Rode, S.; van Liempt, M.; Roos, P.H. Single and concerted effects of benzo[a]pyrene and flavonoids on the AhR and Nrf2-pathway in the human colon carcinoma cell line Caco-2. Toxicol. In Vitro 2011, 25, 671-683. [CrossRef] [PubMed] 